\title{
DEUTERONOMY, A SOURCE BOOK FOR THEOLOGY*
}

Israel's chief contribution to the world is their knowledge of and faith in God. Within the limits of a few centuries and upon the mind and heart of a small nation God wrote in large letters truths about himself and his purposes for Israel and all nations. These letters have been read and studied by many generations since; and by them many have been guided in the way of peace and salvation.

Other nations, some contemporary with and others more ancient than Israel, have left evidences of great empires and buildings, some of which have been retrieved from the sands of the desert. It is noteworthy, however, that, even though nations such as Egypt and Babylonia worshipped their respective gods, knowledge of these gods faded into oblivion with the decline of their worshippers. In contrast, as national Israel ceased to be, the God of Israel continued to be worshipped even though the temple, the house of the Lord God, lay in ruins. And the wonder grew, for people alien to Israel began to embrace the faith of those they had once reviled. Today only students of ancient history have any knowledge of the gods the peoples of the Near East revered, but millions of people throughout the world both know and honor the God who spoke to Israel through Moses.

To know the God of Israel one must read and study Israel's sacred book, the Old Testament which together with the New Testament has also become the sacred Scriptures for all Christians. To obtain the complete knowledge of God one would require an understanding of the whole Scripture - a task beyond the reach of our present purpose. Rather we are selecting Deuteronomy as the source book for the theology elaborated by prophet, poet, and sage. A study concentrated in Deuteronomy will disclose all the important doctrines about God, and will prove the book to be a fountain of living water for all areas of theology.

1.

To discuss the theology of Deuteronomy, we need to take our start at its central declaration of faith, "Hear, O Israel: the Lord our God is one Lord" (6:4). This has become known as the Shemà, so called because this is the first word of the Hebrew text. Judaism has used this passage with the context as its declaration of faith. The evangelist Mark recorded Jesus' quoting it together with the following verse (12:29f).

*) Die Redaksie plaas met genoeë hierdie artikel van Prof. Lester Kuyper, sedert 1939 hoogleraar vir die Outestamentiese vakke aan die Western Theological Seminary te Holland, Michigan, een van die twee opleidingscentra van die "Reformed Church" of Hervormde Kerk van die Verenigde State van Amerika, die kerk wat histories en teologies die naaste staan aan die Hervormde Kerke van Nederland en Suid-Afrika.

T.S. 1. 
Here one finds the most succinct, yet profound utterance about God in the whole Bible. From this point as from the sun all radiance of the Lord God of Israel shines forth.

The Masoretic text $(6: 4)$ contains two large letters ('ayin and daleth) which the Jewish teachers declared were for a guard against errors in copying and in pronouncing. The letters together ('ed) mean witness which has been given the interpretation that Israel is to be God's witness (Isa. 43:10; 44:8); but if not, God will be a quick witness against them (Jer. 11:7; 29:230 Mic. 1:2; Mal. 3:5). Taken separately the daleth, the numerical value of four, indicates the Lord is the one God in the four quarters of the earth and the cayin is the seventy nations who are summoned to hear (Is. $34: 1$ ). C. TAYlor, "Sayings of The Jewish Farhers" (Cambridge: 1877), p. 131.

The decalogue was recited at one time in synagogue services, but was later dropped because of its use by Christians. However, soon RABBI devised ways of finding that the decalogue was embodied in the Shemà. Idem, pp. $132 \mathrm{f}$.

The Shema have been variously translated. The earliest, given by the Septuagint and followed by the Vulgate, renders it even as we have it in the Authorized and the American Revised Versons. "Hear O Israel: the Lord our God is one Lord." Three other translations may be allowed. These are given in the margins of both the English and the American Revised versions: (1) "Jehovah our God, Jehovah is one; (2) Jehovah is our God, Jehovah is one; (3) Jehovah our God is Jehovah alone." These, as GeORge Adam SMith asserts ${ }^{1}$ ) resolve into two concepts: the unity of God in that he is one, and the uniqueness of God in that he is God alone.

Which of the above translations and what consequent interpretation can be adopted have been matters greatly debated by Old Testament scholars. The most common translation, as given in the AV, calls attention to Jehovah (The Lord) as being one, although this proper name hardly admits the epithet "one" since no other god is known bearing that name. If, however, the unity of God is intended, it speaks an important article of faith in a world in which many gods and goddesses were commonly worshipped. For Israel this utterance would forever and finally declare that their God was one. This is a concrete expression, rather than an abstract philosophical formula, that the God of Israel was not appearing polytheistically in various forms, nor was he to be syncretized with the gods of other peoples, a practice so common even in ancient Israel.

The wonder of the Old Testament is the steady persistent witness that God is not many, but one. Elohim (God), a divine name among

1) The Book of Deuteromomy (Cambridge: Cambridge University Press, 1918). p. 98. 
Israel's neighbors, is the common name for God in the Old Testament. It is plural in number and most certainly would have been avoided by us lest there by any taint of polytheism in the monotheistic Scripture. However, the writers of the Bible were most careful in the use of Elohim, for in the approximate 2000 times it appears, it is used with predicates and adjectives singular in number ${ }^{2}$.) When, however, this name is used for pagan gods plural predicates and adjectives appear. The Old Testament, therefore, presents a remarkable testimony for the one God.

For us with a background of many generations of teaching and tradition this doctrine of one God has lost some of its pristine wonder and majesty. To appreciate the monotheistic faith in ancient Israel we should remember that there is no record of the worship of one God in the Near East of that period and that the best expressions of thought never established monotheism. To observe that Israel's faith stood in sharp contrast the many faiths especially on this point is to describe a historical phenomenon that belief in a supernatural revelations only can explain. If for not other reason, this would be ample warrant to believe that this was God's Word committed to Israel through Moses and the prophets.

- The Shema, as translated in (3) above, declares the uniqueness of God in that he is God alone. Both S. R. Driver ${ }^{3}$ ) and A. DillmanN ${ }^{4}$ ) observe that ehadh does not yield this sense for which lebhaddo is the common word (of II Kgs. 19: 15; Ps. 86: 10). It is necessary, therefore, to ascribe to ehadh "one" an unnatural sense. However, the interpretation that Jahweh is the only God serves as a proper introduction to the command in the following verse that the devote Israelite must love God. This hardly could be if he were one God.

As one reflects on the two concepts, the unity and the uniqueness of God, a close relationship between them can readily be observed. For Israel to worship only one God in a setting of many gods is outstanding and unique; and for Moses to teach that God is one is to present a unique God. In other words, to confess and to teach the oneness of God is a unique worship of a unique God.

In other passages this theme is elaborated and given clear articulation. "Unto thee it was showed, that thou mightest know that Jehovah he is God; there is none else besides him ... Know therefore this day, and lay it to thy heart, that Jehovah he is God in heaven above and upon the earth beneath; there is none else" (4:35 39). This declaration is based upon the events of Israel's recent history, events unsurpassed in wonder

')Eleven exceptions are noted by L. KöHLER in Theologie des Alten Testaments. (Tübingen: J. C. B. Mohr, 1936). p. 18.

3) A Critical and Exegetical Commentary on Deuteronomy (New York: Charles Scribner's Sons, 1916), p. 89.

1)Numeri, Deuteronomium und Josua (Leipzig: S. Hirzel, 1886), p. 269. 
during any period of history (v. 32). The deliverance of Israel, a weak people, from mighty Egypt, the wonder of God speaking to them, and and the driving out of the powerful Canaanite nations to give their land for an inheritance to Israel (vv. 33, 34, 38) can but produce one conclusion that "Jahweh he is God, there is none else besides him." This is not a conclusion reached by speculations of philosophy, but by a common sense interpretation of history. Let Israel, therefore, keep it in their heart that their blessed destiny is to worship the one true and failhful God $(7: 9 ; 10: 17)$.

One can hardly refrain from relating the uniqueness of the Old Testament faith to the Gospel of salvation as it is consummated in Jesus Christ. The early Christians were thoroughly imbued with all the claims of the Old Testament and its message, yet they declared that the God of Israel had in a most wondrous manner revealed his love through the death of his Son. This became the unique message apart from which there was no salvation. This message was vouchsafed to the Church for a witness to the world. Without this unique message the Church has no mission; with it the Church becomes the channel of grace to the world.

Within the scope of Deuteronomy's declaration of monotheism the problem arises relative to the reference to the gods of other peoples. If there is only one God, and he is Jahweh, the God of Israel, then an acknowledgement of other gods opens a difficult problem. That there are references to other gods is clear, e.g. the first command enjoins that, "Thou shalt have no other gods before me" (5:7 cf. 6:14, 7:4; 8: 19 etc.). Further, Moses warns Israel against making any graven image and against worshipping "the sun and the moon and the stars. . which Jehovah thy God hath allotted unto all the peoples under the whole heaven" $(4: 19)$. These gods of other nations God has not allotted to Israel $(29: 26)$. One must observe, first of all, that the God of Israel is supreme, he has control over all nations to the extent of assigning each nation its objects of veneration and worship. Worship which is a natural function of mankind falls under the providence of God. Even false religions are taken up in the world plan of God. This statement (rather startling) is to evidence the supreme rule of God. To allow pagan worship beyond the realm of God's sovereignty would make God less than he is. However, the allusion to the heavenly hosts or an acknowledgement of the powers of nature does not thereby declare their reality as God. St. Paul clearly distinguished in his day between the pagan's concept of a false god and the Christian's. "For though there be that are called gods, whether in heaven or on earth; as there are gods many, and lords many; yet to us (italics mine) there is one God" (I Cor. 8: 5f.). Even today we casually refer to gods of other religions w thout any intent of regarding them as real. So also we may consider these references to the gods of Israel's neighbors. 
The persistent emphasis in Deuteronomy as in the entire Bible is that God is revealing himself and his law to Israel. "And Jehovah spoke unto you out of the midst of the fire: ye heard the voice of words, but ye saw no form; only (there was) a voice" ( $4: 12)$. This verse is a sample of a twofold teaching in our book: the first is that Jahweh speaks, the second is that the voice is heard even though no bodily form is seen. This presents in pointed manner both the incredibility of revelation and the miracle of revelation. Within the compass of Israel's experience, not to mention ours, a human voice is only possible from a living body. Remains of Israel's neighboring nations abundantly demonstrate that gods appear in various forms to speak their words. However, Moses declares that God spoke to Israel without the appearance of form. Divine revelation, therefore, is a miracle beyond the realm of natural phenomenon.

This miracle of God's speaking or revealing himself occurs frequently in the course of Biblical history. God revealed himself through the oath to the patriarchs, Abrham, Isaac and Jacob, that they and their seed should possess this land $(1: 8 ; 6: 10,18,23$ etc.). It is with the fathers that God established his covenant and his lovingkindness which he desires to preserve with Israel $(7: 9,12)$. Within the memory of the tribes about to cross the Jordan, the miracle of God's presence and deliverance was clearly demonstrated. God also had given the law through Moses by which Israel should find it life and prosperity. God's word to Israel would continue beyond the present into the future for the office of the prophet is to be established through which God would continually speak to the people $(18: 18)$.

The purpose of revelation is to afford the people instruction. It is obvious that Israel now entering the experience of becoming a nation would need much instruction. Such no doubt was the reason for the civil laws of Deuternonomy. However, more fundamental instruction is designed than the establishing of the legal framework of a nation. "Out of heaven he made thee to hear his voice that he might instruct thee" (4: 36). The Hebrew verb yissar involves the concepts of discipline, correction and chastisement (cf. I Kgs. 12:11; Ps. 39:11 [H. v. 12]). This instruction or education concerns itself with the moral and spiritual nature of the people. Throughout the wilderness wandering God subjected Israel to the privations of the desert to discipline them as a father would discipline his son $(8: 2-5)$. God's word is the power by which men live, for it directs the heart and affections in ways of obedience and reverence.

Any reflection on the purpose of the Bible, the revelation of God, must inevitably establish the Scriptures as the rule of faith and practice. We greatly confuse the insights and precepts of the Bible when we make it a test book for natural science or for ancient history. Our civilization 
has acquired a profound knowledge of the material resources long latent in the world, yet nations are constantly involved in hostilities which betray a lack of spiritual and moral discipline. Ancient Israel, even as we today, needed the Word of God to direct and to correct the impulses and motivations of the heart.

We know the paths wherein our feet shoud press,

Across our heart are written thy decrees,

Yet now, O Lord, be merciful to bless

With more than these.

Grant us the will to fashion as we feel;

Grant us the stregth to labor as we know;

Grant us the purpose, ribbed and edged with steel,

To strike the blow.

Knowledge we ask not, knowledge thou hast lent.

But Lord, the will - there lies our bitter need.

Give us to build above the deep intent

The deed, the deed.

God speaks to Israel through Moses to establish a covenantal relationship with his people. Perhaps it would be more correct to say that God speaks to maintain his relationship, for we are constantly reminded of God's oath or covenant with the fathers, as we have already noted. Yet in this relationship with Israel the basic factors of God's encounter with mankind to establish his Church are clearly delineated so that New Testament writers hark back to Old Testament terminology to describe the relationship which exists between God and the Church.

God chooses Israel to be his people. This fact is emphasized by frequent repetitions. "Jehovah, thy God hath chosen thee to be a people for his own possession, above all peoples that are upon the face of the earth" (7:6 cf. also v. $7 ; 4: 37 ; 1015 ; 14: 2)$. Not because of greatness in number or strength is Israel chosen $(7: 7)$. Had God intended to make an auspicious beginning for his people, he coule have selected either Egypt in its power or any of the nations of the Fertile Crescent (cf. $7: 1 ; 9: 1$ ). World prestige or prominence is no criterion by which God would select his people.

God's choice is motived by love for Israel. "Because Jehovah loveth you" is the reason given for choosing ( $7: 8$, cf. also v. 7). Moses carries this love back to the times of the patriarchs whom God loved and therefore he chooses their seed $(4: 37,10: 15)$. In the days to come if Israel will keep and do the ordinances of God, then God will love them and prosper them $(7: 13 ; 23: 5$ [H.v. 6]). This attribute of God is not mentioned in other parts of Pentateuch but finds expression in some of the prophets. Hosea describes God's relationship to Israel in terms of the marriage bond (1-3) and in terms of a father's love for a son (11: 1-4; cf. also 14:4). This idea of God's love for Israel recurs in some later prophets as Jer. 31 . $31: 3$; Isa. 43:4; 63:9: Mal. 1:2. 
Why should Israel become the objects of God's special love? To answer this, one is confronted with the mystery of divine grace. To be sure, Deuteronomy relates this manifestation of divine favor to God's oath made to the fathers and the covenant established with them. In some measure, therefore, God is mindful of his plan of redemption which is progressing through history. However, there is more than a theological necessity or determinism that brings Israel within the realm of God's choice here, for God has a present and personal affection for his people. Divine love reaches out to invite a weak and oppressed people to a new life. This kind of love touches the unlovely, as in the case of Israel who murmered and rebelled against the God who saved them. Israel was emphatically informed by Moses that their advantage and prosperity would in no wise result from merit. It is not their righteousness that will drive out the Canaanite for they are a stiffnecked and rebellious people $(9: 4-7)$. The miracle of divine love is as Paul declares: "God commendeth his own love toward us, in that, while we were yet sinners, Christ died for us" (Rom. 5: 8).

God's favor would also attend Israel in the conquest of Canaan. Israel well knew the formidable strength of the inhabitants of Canaan whom they could hardly expect to dispossess $(1: 28 ; 9: 1 \mathrm{f})$. However, the outcome of the conquest is not in the hands of Israel for it is Jahweh who is a devouring fire going before to drive out the enemy $(9: 3$; cf. $1: 30$; $7: 21 \mathrm{f})$. Further Jahweh is to give them a land of wealth and resources already developed $(6: 10 \mathrm{f} 8: 7-9)$. All this is designed to teach that God's unmerited favor is responsible for Israel's success and prosperity.

To these evidences of God's favor and love Israel must respond with hearty affection and obedience. "And thou shalt love Jehovah thy God with all thy heart, and with all thy soul, and with all thy might" $(6: 5)$. Love for God, which is alluded to in the decalog (5:10; cf. 7:9; Ex 20:6), is a peculiar emphasis of Deuterononmy not found in the rest of the Pentateuch. It incorporates on the one hand the innermost attitudes of the individual and on the other hand the observance of all commands in the worship of God. All conduct and worship must be motivated by love $(7: 9 ; 10: 12 ; 11: 1,13,22 ; 13: 3$ [H. 4];19:9; 30:6, 16, 20).

If in the future Israel fails or refuses to love and serve Jahweh their God, then God's judgments shall come upon them and all the favors now in prospect will be taken from them. Disobedience and apostasy will result in grave disasters or in the disgrace of exile. In other words, God's special favor in no wise may be regarded as immunity against punishment in the event of moral or spiritual declension (4:25-27 6:14f; $8: 19 f$.)

These data in Deuteronomy offer an important and interesting balance for our kowledge of God. Cari Steuernagel ${ }^{5}$ ) has called attention to two elements in God's relationship to Israel. The deliverance of Israel

5) Die Entstehung des deuteronomischen Gesetzes (Berlin: 1901), pp. $122 \mathrm{ff}$. 
from Egypt and the possessing of the promised land are expressions of God's faithfulness to his covenant. However, if God were controlled entirely by faithfulness to the covenant, then his moral character would be called in question. Therefore it is that God punishes the sins of his people to such extent that regard for the covenant is lost. In contrast, proper response by his people in ethics and worship is a guarantee for God's favor and faithfulness. This demonstrates clearly that God is a moral being. On the other hand, if God were merely the incarnation of ethics to prosper all good and to destroy all evil, then the reward principle for right living would be established and self righteousness would become imminent. Then there would be no occasion for divine grace, for God would govern according to a merit system. Since we know of what sinful disposition Israel was, they soon would be dropped from God's program. However, these apparently exclusive concepts, God's gaithfulness to his covenant and his moral character, are preserved in harmonious balance throughout our book.

A corollary to this may be observed in Israel's conduct before God. Since God is a moral being, Israel is to live righteously. They are constantly confronted with the moral demands of God. "This do and ye shall live." Under no circumstance can they indulge in sinful practice on the pretext of being the chosen people. However, in times of success and prosperity Israel is never to manifest self-righteous pride, for prosperity as well as the possession of the land occurs because of God's favor to Israel (8: $189: 4-6)$. "Even so ye also, when ye shall have done all the things that are commanded you, say, we are unprofitable servants; we have done that which it was our duty to do" (Lk. 17:10).

III.

The prophets and psalmists in ancient Israel were devout teachers of history. Even so in Deuteronomy history, primarily of Israel, becomes an important factor of the book. It is significant to note that the command to keep the Sabbath is to commemorate the deliverance from Egypt (5:15), which is an interesting difference from the Exodus decalog in which the creation of the world is commemorated (20:11). Each Sabbath all the people are to recall the historical event of Israel's national birth. In presenting his first fruits to the priest before Jahweh the individual worshipper is likewise required to recite a liturgy of historical import.

A Syrian ready to perish was my father; and he went down into Egypt, and sojourned there few in number; and he became there a nation, great, mighty and populous. And the Egyptians dealt ill whith us and afflicted us, and laid upon us hard bondage; and we cried unto Jehovah, the God of our fathers, and Jehovah heard our voice, and saw our affliction, and our toil, and our oppression; and Jehovah brought us forth out of Egypt with a mighty hand, 
and with an outstretched arm ... And now, behold, I have brought the first of the fruit of the ground, which thou, O Jehovah, hast given me (26:5-10).

This passage and the Sabboth command are examples to indicate that the worshipper was being taught that Jahweh, the God of Israel, was active in history.

Israel confessed Jahweh as God of history for didactic purposes. The not infrequent reminders of God's delivering Israel from bondage are to awaken compassion and concern for the less favored classes, such as the slave or the stranger $(5: 14 \mathrm{f} ; 15: 13 \mathrm{ff} ; 16: 11 \mathrm{f} ; 24: 17 \mathrm{f}, 21 \mathrm{f})$. The liturgy cited above for the offering of the first fruit was to incite the worshipper's gratitude not merely for the prospect of harvest but especially for the divine control of history that made this land his cherished possession. The many years of wilderness wandering resulted from the nation's rebellion against Jahweh's command to conquer the Amorites from Kadesh-Barnea (1:19-36). A hasty and superficial repentance that induced the people to go up against the Amorites ended in a humiliating defeat ( $v v$ 41-45). The peaceful passage through Seir and through Moab was to preserve this land as possessions for the Children of Esau and of Lot, tribes related to Israel $(2: 5,9,19)$. However, the campaign against Sihon, king of Heshbon, was instigated because Jahweh had hardened the king's heart (2:30), which placed God's providence and control in every event, even in the obstinacy of the enemy (cf. Ex. $4: 21 ; 7: 3 ; 10: 1$, 27 ; 14:4, 8; Jos. 11:20; I Kgs. 12:15). ${ }^{6}$ ) Israel was assured that God would drive out the strong Canaanites not because of Israel's righteousness but because of the wickedness of those nations $(9: 5 ; 18: 12)$. The moral and social standards even of pagan nations were brought before the bar of God's judgdment. The course of Israel's history Jahweh promised to direct according to the nation's obedience or disobedience, which would bring either national strength or national disaster ( $4: 25 \mathrm{ff} ; 28: 1 \mathrm{f}, 25 \mathrm{ff})$.

In a summary of the Theology of Deuteronomy we should note the recurring theme that God is speaking to reveal himself to Israel. This presents the unique nature of his being, and especially his great concern for Israel's present welfare and for their faithful service to God in the promised land. Altogether the message of Deuteronomy is God's disclosure of his faithfulness to the covenant as the plan of redemption progresses in Israel's history.

One need hardly mention that one of the main tenets of Christian Theology is that God has revealed himself through prophets and apostles as the promises of the old covenant consummate in the coming of the the Messiah, Jesus Christ, our Lord. God has presented the Gospel in his Son who came in the fulness of time within the framework of history

- An interesting discussion on the problem of Providence and Freedom is given by W. Eichrodt in Theologie des Alten Testaments, II Teil (Leipzig: J. C. Hinrichs, 1935), pp. 93-95. 
o redeem mankind in its historical setting. Today, therefore, Christians should be reminded that the Gospel of salvation, which reaches back in history to pre-Israelite times, to the patriarchal era, has reclaimed people in every segment of history and that now it can miraculously deliver our sinful tragic world order. The Gospel is the dynamic for the individual and for society that can bring order out of chaos. It is the power of God to everyone that believes.

Another observation from our study concerns itself with the tender and intimate relationship which exists between God and his people. No cool indifference can be found. God loves Israel; he has loved the fathers; he promises to love them as a father. And yet never does this love become maudlin or sentimental. This should awaken a response of love toward God and compassion for the oppressed. Deuteronomy may well serve as a source book for the Gospel's portrayal of God's love for the world. The heart beat of divine grace can clearly be felt in our book and equally well may Christians respond to the overtures of love as Moses directed his people "to fear Jehovah thy God to walk in all his ways, and to love him, and to serve Jehovah thy God with all thy heart and with all thy soul" (10: 12).

Western Thelogical Seminary,

LESTER J. KUYPER.

Holland, Michigan, U.S.A. 